Institute of $\mathbf{F}_{\text {ood and }} \mathbf{A}_{\text {gricultural }} \mathbf{S}_{\text {ciences }}$

\title{
Florida Solid and Hazardous Waste Regulation Handbook: Occupational Safety and Health Act (OSHA) ${ }^{1}$
}

\section{Michael T. Olexa, Aaron Leviten, and Kelly Samek ${ }^{2}$ \\ What Is the Occupational Safety and Health Act (OSHA)?}

Congress passed the Occupational Safety and Health Act to assure that the workplace environment is safe and healthy. To fulfill this purpose, OSHA authorized the Secretary of Labor, who is the head of the Occupational Safety and Health Administration, to set and enforce safety standards for employees working in dangerous circumstances such as handling hazardous wastes.

\section{How Is OSHA Enforced?}

All persons and facilities must deal directly with the federal Occupational Safety and Health Administration to ensure compliance with OSHA.

\section{Who Enforces OSHA?}

Since Florida has not yet established its own health and safety program, the federal Occupational Safety and Health Administration is responsible for ensuring compliance. The Occupational Safety and Health Administration may conduct site inspections and require the employer to make self-evaluations.
You should contact the Occupational Safety and Health Administration to gather more information about the safety requirements for employees using pesticides, gasoline, or any other hazardous or potentially hazardous substance.

\section{Are Surprise Inspections Allowed?}

Yes. The Occupational Safety and Health Administration needs only reasonable suspicion of a violation of OSHA's safety standards before it may enter the facility to conduct an inspection without prior notice. The inspection, however, must be conducted at a reasonable time.

\section{What Are Employer Self-Evaluations?}

The Occupational Safety and Health Administration may require the employer to make periodic self-evaluations to ensure compliance with safety requirements. Employers are encouraged to contact the Occupational Safety and Health Administration to gather more information about these evaluations. Those subject to these requirements may include:

1. This is EDIS document FE447, a publication of the Department of Food and Resource Economics, Florida Cooperative Extension Service, UF/IFAS, University of Florida, Gainesville, FL. Published December 2003. Please visit the EDIS website at http://edis.ifas.ufl.edu.

2. Michael T. Olexa, Professor in the Department of Food and Resource Economics and Director of the Agricultural Law Center, Florida Cooperative Extension Service, UF/IFAS, University of Florida, Gainesville, FL, and Member of the Florida Bar and Chair of the Agricultural Law Committee of the Florida Bar; Aaron Leviten, Attorney in Orlando and guest lecturer on pesticide litigation at the University of Florida; and Kelly Samek, 2003 graduate of the Levin College of Law at the University of Florida.

The Institute of Food and Agricultural Sciences is an equal opportunity/affirmative action employer authorized to provide research, educationa information and other services only to individuals and institutions that function without regard to race, color, sex, age, handicap, or national origin. For information on obtaining other extension publications, contact your county Cooperative Extension Service office. Florida Cooperative Extension Service/Institute of Food and Agricultural Sciences/University of Florida/Christine Taylor Waddill, Dean. 
- construction workers.

- pesticide applicators.

- heavy equipment users.

- toxic chemical users.

\section{What Are the Requirements for Hazardous Materials?}

OSHA's health and safety standards are very comprehensive. The standards for handling hazardous wastes include requirements for:

- a site-specific analysis and a plan for protection.

- a minimum level of training for employees exposed to hazardous waste and toxic substances.

- regular medical examinations of employees who handle hazardous substances,

- appropriate personal protective equipment.

- maximum exposure limits.

- engineering controls.

- an informational program to employees who regularly handle hazardous wastes.

- an emergency response plan for accidents involving hazardous wastes.

- handling, transporting, labeling, and disposing of hazardous wastes.

With respect to pesticides, OSHA requires compliance with EPA regulations established under the Federal Insecticide, Fungicide, and Rodenticide Act (FIFRA). The label instructions on pesticides ensure that employers and employees are kept safe. Violating the pesticide labeling requirements can trigger penalties under OSHA as well as FIFRA.

\section{What Are the Other Requirements of OSHA?}

OSHA also regulates many other activities commonly associated with agriculture, including:
- the construction of, or repairs on, farm buildings.

- the use of heavy machinery.

- the handling of toxic chemicals.

A discussion of these provisions is beyond the scope of this handbook. You should contact OSHA for more information. Penalties for violations may be severe.

\section{What Are the Penalties under OSHA?}

Non-compliance with the standards discussed above may subject you to severe civil and criminal penalties. You may also be subject to private lawsuits if an employee is intentionally harmed.

Penalties under OSHA can affect:

- Any employer who violates any part of OSHA or the regulation that is considered "non-serious" may be fined up to $\$ 7000$ for each violation.

- Any employer who commits a "serious violation" under OSHA shall be fined up to $\$ 7000$ for each violation.

- Any employer who violates any of the posting requirements under OSHA shall be fined up to $\$ 7000$ for each violation.

- Any employer who willfully or repeatedly violates OSHA or the regulations may be assessed a fine not less than $\$ 5000$ but not more than $\$ 70,000$ for each willful violation.

- Any employer who fails to correct a violation within the time given under OSHA may be fined up to $\$ 7000$ for each day the violation continues.

\section{Acknowledgments}

The authors are indebted to the personnel of both state and federal agencies who gave their time and advice in the preparation of this handbook. The authors are also indebted to the following University of Florida personnel for a review and critique of the first draft of this publication: Dr. Thomas Dean, 
Pesticide Education Specialist, and Dr. Norman

Nesheim, Pesticide Information Coordinator. Special

recognition is also due to Mr. Richard Budell of the

Office of Agricultural Water Policy of the Florida

Department of Agriculture and Consumer Services

for providing funds for the development of this

handbook.

This handbook is designed to provide an accurate, current, and authoritative summary of the principal Florida laws that directly or indirectly relate to agriculture. It should provide a basic overview of the many rights and responsibilities farmers and farmland owners have under Florida laws. The reader is provided information about these rights and responsibilities and the appropriate contacts for more detailed information. However, the reader should be aware that because the laws, administrative rulings, and court decisions on which this publication is based are subject to constant revision, portions of this publication could become outdated at any time. Many details of cited laws are also left out due to space limitations.

This handbook is distributed with the understanding that the authors are not engaged in rendering legal or other professional advice and the information contained herein should not be regarded or relied upon as a substitute for professional advice. It is not all-inclusive in providing information to achieve compliance with laws and regulations governing the practice of agriculture. For these reasons, the use of these materials by any person constitutes an agreement to hold harmless the authors, UF/IFAS, the Agricultural Law Center, and the University of Florida for any liability claims, damages, or expenses that may be incurred by any person as a result of reference to or reliance upon the information contained in this publication. 